International Journal of English Language and Literature Studies

$\operatorname{ISSN}(e): \quad 2306-0646$

$\operatorname{ISSN}(p): \quad 2306-9910$

DOI: $10.18488 /$ journal.23.2021.101.46.59

Vol. 10, No. 1, 46-59.

(C) 2021 AESS Publications. All Rights Reserved.

URL: www.aessweb.com

check for
updates

\title{
DIALECTICAL UNITY: INTERACTIVE INTERWEAVING OF CONFLICTING VARIABLES WITHIN SECOND LANGUAGE DEVELOPMENTAL PROCESSES
}

Beata K

Raszkowska

\author{
School, College and University Teacher, Independent Scholar, Birmingham, \\ UK. \\ Email:braszkoweska@mail.com
}

(T) Check for updates

.

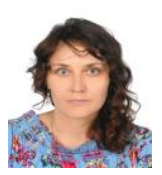

\section{Article History}

Received: 22 October 2020

Revised: 24 November 2020 Accepted: 29 December 2020 Published: 19 January 2021

\section{Keywords}

Dialectical unity

Interweaving variables

Second language (L2)

development

SLA

Linguistic

Cognitive

Affective

Social

Vygotsky.

\begin{abstract}
Amongst varieties of theories in the field of Second Language Acquisition (SLA) there is a dearth of research on the interrelationship and coexistence of different ratios and variables among linguistic, cognitive, social or emotional forces in second language (L2) developmental processes. To bridge this gap, this paper adapts a Vygotskian interpretation of dialectics to demonstrate a dialectical unity among these conflicting forces. Thus, departing from any political connotations that dialectics are usually associated with or disputes over Vygotsky's tendency to disparity and contradictions, the present paper mainly aims to throw light on the possibility of viewing L2 developmental processes through the prism of this alternative dialectical perspective. To that end, the paper does not seek to equate Vygotsky, dialectics and SLA but rather to pose new questions from a dialectical perspective with the aim of stimulating further research on this matter. The study adopts a traditional literature review approach by selecting a few empirical and theoretical studies that seem to bear on the dialectical thought process without necessarily explicitly referring to it. The analysis suggests that such variables as cognition, affect and sociocultural factors may indeed co-exist to a greater or lesser extent in an ongoing dialectical development.
\end{abstract}

Contribution/ Originality: The paper is the first study to investigate the concept of dialectical unity as applied to second language developmental processes. It proposes that the different degrees of ratios of these variables to each other and their interactive and interwoven reactions have the potential to influence SLA in diverse ways.

\section{INTRODUCTION}

In Second Language Acquisition (SLA) research, different theoretical perspectives seem to dominate the field. SLA itself emerged not only from the discipline of linguistics but also from disciplines such as cognitive science, psychology, sociolinguistics, psycholinguistics and education (Larsen-Freeman, 2018; Mitchell \& Myles, 2004; Neupane, 2019). Generally speaking, its theoretical beginnings started with a behavioristic view of second language learning (SLL) derived from the work of such scholars as Thorndike (1932); Bloomfield (1933) and Skinner (1957). It then shifted its focus to an innatist understanding of SLA, which has its origins mainly in Chomsky's (1959) work, which was influenced to some degree by Piaget's theory of cognitive development in psychology (Mitchell \& Myles, 2004). Subsequently there was a shift in the theories of Corder and Selinker, which are often seen as seminal in SLA (Larsen-Freeman, 2018). Thus, for instance, Corder (1974) introduced the concept of error analysis, whilst Selinker (1972) that of "interlanguage". 
In the late 1970s and the early 1980s, Krashen's highly influential ideas focusing on the distinction between learning and acquisition gradually emerged (Krashen, 1984; Krashen., 1985). Alongside the social turn (Block, 2003), there was a progressive inclination towards social, as opposed to purely cognitive, dimension of SLA (Ellis., 2020; Larsen-Freeman, 2018). Continually evolving, through a number of phases, the field eventually arrived at a complex dynamic systems theory (De Bot, Lowie, \& Verspoor, 2007; Larsen-Freeman \& Cameron, 2008; Larsen-Freeman, 2018) which, in contrast, emphasizes the nonlinear and complex nature of SLA (Ellis, 2020; Menezes, 2013). The theoretical expansion did not stop there though. On the contrary, it expanded into, for example, the so-called multilingual turn in the 2010 s that stands in opposition to monolingual ideologies (Ellis, 2020; May, 2014; Meier, 2017; Ortega, 2014). These gradual changes in the interpretation and understanding of SLA were captured by Neupane (2019) in three main characteristic phases, "background, formative, and developmental”. Perhaps unsurprisingly, among these “[c]ountless theories” (Menezes, 2013) a transdisciplinary approach to SLA (Douglas Fir Group, 2016; Ellis, 2019; Hall, 2020) is emerging providing an "unbounded perspective on SLA" (Ellis, 2019).

Keeping in mind the idea of trans-disciplinarity and at the same time departing from dichotomous or evaluative considerations of SLA, this paper takes the concept of dialectics embedded in Vygotsky's work to propose an alternative dialectical reading of second language (L2) development. The paper neither critiques nor inclines to any particular theory but rather aims to inquire whether there are any dialectical interrelations among a wide range of opposing variables such as linguistic, cognitive, affective and/or social, participating in language developmental processes. In this vein, the study asks whether the ratios of these opposing forces might so interact and impact with each other to create subsequent ever-evolving and dynamic entities, which are, nevertheless, unified so as to create a harmony of opposites, impacting second language development. The focus here is not on any particular age group or context but rather on the ratios among variables which might differ from person to person, from situation to situation, context to context. Against this background, it may be noted that the phenomenon of correlation still remains comparatively new in Western psychology and neuroscience (Lantolf \& Swain, 2020).

(Dafermos, 2018) identifies the fact that the need for the promotion of the dialectical approaches emerges in the concrete sciences, when their subject matter is examined as complex and changing, rather than trivial and static. Recognizing that the notion of dialectical unity in SLA has not been treated in much detail as yet, this review seeks to raise questions rather than answer them and calls for further research on the notion of dialectics in SLA. To this end, in the first place the key term, second language development, used in the paper is clarified. Next, the idea of dialectics and its relevance to the field of SLA is introduced. Finally, a number of selected empirical and theoretical studies are exemplified to identify any echoes of possible dialectics embedded within the chosen studies, yet not necessarily acknowledged by the authors. Due to the limited space dedicated to the topic under scrutiny, a comprehensive review of SLA research literature as well as studies dedicated to the notion of dialectics was not possible. However, an attempt has been made to briefly outline the key concepts attached to SLA and dialectics.

\section{SECOND LANGUAGE DEVELOPMENT}

In SLA, the polarized terms, second language (L2) learning and acquisition are commonly used. To move away from any form of dichotomy, L2 development is used instead in this paper. Additionally, the term L2 refers here to either second or any additional language developed in different ways and contexts. Before proceeding, however, it is crucial to clarify their meaning so that the term 'development' will become clearer. The distinction between these two terms is usually associated with Krashen and his acquisition-learning hypothesis (Krashen, 1985) which became prominent at the time when teaching approaches based on behaviorism were declining (Lightbown \& Spada, 2013). Krashen (1985) was claiming that a new language should be acquired in a way similar to the mother language (L1), that is, subconsciously and through exposure, rather than being learned in an explicit and guided manner as in teaching in schools. To put it differently, language is acquired through comprehensible input, suggesting that the 
input, is "the only true cause of second-language acquisition" (Krashen, 1984). This theory is thus inclined towards Chomsky's Lightbown and Spada (2013) view of language (Lightbown \& Spada, 2013), in which each person is born with an innate ability to 'pick up' a language by means of a language acquisition device (LAD) embedded in the mind and through an inborn predisposition to acquire grammar thanks to an innate Universal Grammar (Tan \& Shojamanesh, 2019).

Krashen's highly influential theory contributed to the reduction of explicit learning (EL) in favor of a more implicit approach to learning (IL) as well as the expansion of methods promoting native-like language learning. However, growing research on bilingualism (Baker \& Jones, 1998; Baker, 2011; Bialystok, Craik, \& Luk, 2012; Cummins, 1976; Cummins, 1996, 2000; Skutnabb-Kangas \& Toukomaa, 1976) is gradually showing the limitations of this method (Liu, 2015). For instance, Swain (1985) coined the notion of comprehensible output, which indicates a need for the action-process of producing language (speaking and writing) by participating in the process of second language learning as opposed to a sole reliance on listening and reading. Likewise, Schmidt (1990) argues that input turns into intake only at the moment of conscious awareness of linguistic forms. This idea was subsequently captured in the name of the noticing hypothesis. Swain (2006) later proposed another expression, "languaging", suggesting that a learner engages in a cognitive activity through speaking and writing, making a cognitive process an active engagement. Additionally, for Swain and Lapkin (2013) languaging also infers "the use of language to mediate cognition and affect".

Further advancement in the field of SLA also emphasized the importance of the cognitive and literacy common ground across languages, also known as Common Underlying Proficiency (CUP), proposed by Cummins (2000). In his Threshold Level Hypothesis Cummins (2000); Cummins (1996) opposed the balance theory where two languages do not transfer but operate separately at the expense of $\mathrm{L}_{1}$ (Baker, 2011) and claimed that the better is the L1, the better the L2 will be. The continuously developing and changing research into SLA also sees language as more than a means of everyday communication but also as a thinking tool to bring cognitive benefits (Kozulin, 2003; Mercer \& Littleton, 2007; Swain \& Lapkin, 2013). Interestingly enough, Watts-Taffe and Truscott (2000) argue that oral skills may not always precede written skills. The importance of the relation between written signs and oral speech has increasingly emerged in the literature (Jablonski, 2002).

In the light of this vast array of theories, the paper chooses to employ the term 'development' to fuse their connotations into one through the choice of this terminology. As a consequence, Vygotsky's notion of "the dialectic within a monistic framework" (Robbins (1999): vi, italics in original) is discussed in the next section and later expanded to the chosen studies to illustrate this point. After a general introduction to dialectics, Vygotsky's dialectics will be explored as an approach that seems to offer, among other things, a more unified and integral perspective on L2 developmental pathways that is dependent on the unique individual, and their dispositional and situational characteristics. Restating (Dafermos, 2018) it may be disputed that:

Developing a dialectical framework in psychology and in other disciplines opens up new horizons for thinking and acting in a complex and contradictory world. Therefore, it became necessary to investigate dialectical thinking as a mature and advanced form of thinking, a creative way to cope with contradictions in the real world as well as in the process of its theoretical reflection.

\section{DIALECTICS AS AN INTERACTIVE HARMONY OF OPPOSITES}

\subsection{Dialectics in General}

Dialectics is usually associated with philosophy. In general, it maintains that seriously considered opposing or contrasted ideas or arguments can through dialogue arrive at a form of consensus or common ground that may enable seemingly contradictory elements to be held in creative tension in a new synthesis. Its roots go back to ancient times and such prominent thinkers as Plato or Aristotle, hence known as the Greek Dialectic (Wong, 2006). It has progressed through time to more modern philosophers, for example Hegel, Marx and Engels (Dafermos, 
2018; Glassman, 2000) in western philosophy. Wong (2006) also reminds the reader of the contemporary German negative dialectic, the Chinese Dialectic, and the Indian negative dialectic; whilst (Glassman, 2000) recognizes the fact that the philosophical underpinnings of the concept of dialectics tend to associate it with a philosophical stance in lieu of scientific reasonings. Possibly, for the same reason, in the western world dialectical thinking has played a side-lined role (Dafermos, 2018) and unquestionably in the discipline of SLA. In fact, it seems that the notion of dialectics has only recently entered SLA through Vygotsky's Sociocultural Theory (SCT). With this in mind, the idea of dialectics introduced in this paper is not applied from a particular philosophical tradition but rather as a means to illustrate the linguistic concept of second language development.

\subsection{Vygotsky and Dialectics}

The beginnings of SCT can be found in Vygotsky's proposition of cultural-historical psychology (Ohta, 2016) according to which cognition is interpreted as a developmental-historical process formed continuously over changing times and circumstances (Daniels, 2007; Daniels, 2008). It subsequently goes beyond pure cognitivism by proposing that "through others we become ourselves" (Vygotsky, 1997b). Here a human mind is seen as a "flexible, dynamic system", not as a "static structure" (Van Der Veer, 2007) and as such is in an ongoing process of becoming (Daniels, 2007; Daniels, Cole, \& Wertsch, 2007; Swain, Kinnear, \& Steinman, 2011). This approach to cognition refers to the 'individual as a whole' and as such equally affects individual function as well as personality formation (Kozulin, 1990; Newman \& Holzman, 1993; Robbins, 2007; Tappan, 1997; Tappan, 1998). Hence, a child's development for Vygotsky is perceived from a specific theory of psychological development (Lantolf \& Beckett, 2009). It was conceivably for the same reason that he (Vasileva \& Balyasnikova, 2019) favored the terms 'cultural psychology' or 'cultural-historical psychology' (Lantolf \& Beckett, 2009). Although it was in fact Wertsch (1985) who popularized the phrase 'sociocultural'.

The fact that there are various translations of Vygotsky's work that are not always accurate (Van der Veer \& Yasnitsky, 2011) and various interpretations of his theories (Robbins, 2007) which alongside Vygotsky's shifting views over the course of time, possibly contributed to the varied Vygotskian and post-Vygotskian interpretations in the SCT field itself (Ohta, 2016). Yet, despite the arguable fertility of "Vygotsky's philosophy" (Liu \& Matthews, 2012) it tends to be predominantly identified with, for instance, the Zone of Proximal Development (ZPD) (Barrs, 2017; Chaiklin, 2003; Veresov, 2004) the impact of social interactions on the development of cognition (Lantolf, 2003; Van Compernolle.. 2015) the concept of mediation (Appel \& Lantolf, 1994; Kozulin, 2003; Lantof \& Thorne, 2006; Lantolf \& Beckett, 2009; Lantolf, Thorne, \& Poehner, 2015; Wertsch, 2007) and ultimately dynamic assessment (Lantolf \& Poehner, 2010). Vasileva and Balyasnikova (2019) recognize, on the one hand, the illustrious character of his work and, on the other, its outdatedness, possibly triggered by these erratic translations and 'free' variations of interpretations of his theories. Despite these drawbacks, the authors at the same time accept the renewable and interdisciplinary character of his theories. In this light, it might be argued that with the emergence of the Douglas Fir Group (2016) and the greater realization of the need for more prominent "transdisciplinary, diversity, and collaboration" (Ellis, 2019) Vygotsky's theories might also take another dimension in the discipline of SLA.

In parallel, it is also crucial to acknowledge (Van Der Veer, 2007) that some elements of Vygotsky's proposition still stay unexplained as "he took some great unanswered mysteries to his tomb" dying prematurely at the age of 37. Presumably, this could be one of the reasons why Vygotsky's self-description as a dialectician went unnoticed. To quote Vygotsky (1997a) himself: "We are dialecticians. We do not at all think that the developmental path of science follows a straight line, and if it has had zigzags, returns, and loops we understand their historical significance and consider them to be necessary links in our chain, inevitable stages of our path.”

Notwithstanding the fact that his interpretation of dialectics was influenced to a lesser or greater degree by Hegel's, Engel's and Marx's dialectics (Dafermos, 2018) it was still not bound to any theories per se, but rather 
remained idiosyncratic and individualistic. Similarly, inasmuch as Vygotsky favored Spinoza's philosophy (Dafermos, 2018; Robbins, 1999; Robbins, 2007; Severac, 2017; Yaroshevsky, 1999) by agreeing with the Dutch Jewish philosopher on the unity of mind and body (Dafermos, 2018), it analogously assisted him in questioning Cartesian mind-body dualism by placing polarities within a unified whole (Robbins, 1999; Yaroshevsky, 1999). His approach transcended the one-sided view of the human as either a spiritual or physical entity (Vygotsky, 1999; Yaroshevsky, 1999). In this sense, biology is not separated from the mind, behavior from consciousness, individual from social, external from internal or cognition from emotions (Robbins, 2007; Swain, 2013; Vadeboncoeur, 2013; Vadeboncoeur. \& Collie, 2013; Vygotsky, 1987; Vygotsky, 1997b; Vygotsky, 1999). On the contrary, although the interactions among "the lower/higher nature, body/soul, passion/will” (Robbins, 1999) cause dramatic collisions (Veresov, 2004; Veresov, 2016) they also interact to create a dialectical unity in this ongoing developmental process.

To put it differently, qualitative, as opposed to quantitative, transformations take place and have an impact on a particular path of development in this complex dialectical process, thus resulting in a development that is never static or linear, but rather dynamic and uneven (Dafermos, 2018). Thereby, qualitative changes, even though they involve internal struggles, conflicts and crises, characterized by Vygotsky (1997b) as "regression, gaps, zigzags, and conflicts", occurring due to unavoidable but necessary interactions among contradictory forces, concurrently carry a moving transformational force (Dafermos, 2018; Veresov, 2016; Veresov \& Fleer, 2016). As a result, this process entails both moving forward and backward combined in an asymmetrical developmental progression. In this way, " $[\mathrm{t}]$ he older functions continue to exist as subordinate units of the new whole" (Robbins, 1999 italics in original). (Vygotsky, 1999) further asserts: "But the regression is only a seeming regression: development, as frequently happens, moves not in a circle in this case, but along a spiral returning on a higher place to a point that was passed."

This "developmental paradox" (Kozulin, 1990) or "the drama of development" (Vygotsky, 1998) is not free from emotions and for the same reason includes the integration of cognitive and affective elements. In this way, such a process turns into "perezhivanie", the term also coined by Vygotsky (Lantolf \& Swain, 2020; Michell, 2016; Veresov.. \& Fleer, 2016) that is, an "experiencing" (Michell, 2016) or "lived experience," or "lived through experience" (Vadeboncoeur \& Collie, 2013) which Smagorinsky (2013) also calls a meta-experience. It is because a human being is regarded as "an integral and active psychophysical being” driven by both bodily and spiritual needs (Yaroshevsky, 1999 ) italics mine) and not either/or. As a consequence, this inter- dialectical and intra-dialectical process "obtains its concrete psychological content" (Veresov \& Fleer, 2016) italics in original) when the symbiosis and the struggle of contraries is being experienced. This, in turn, is indicative of "the unity of the cognitive and the affective-motivational in the activity of personality" (Yaroshevsky, 1999) italics in original) because "in every idea, there is, in a processed form, an affective relation of man to the reality represented in the idea” (p.266).

By the same token, drawing on Vygotsky's concept of inseparability of cognition and emotion, Swain (2013) claims that, L2 learning is not just a cognitive undertaking but also an emotional one. Within this framework L2 development is not emotionless. On the contrary, it embodies social and emotional learning (Vadeboncoeur \& Collie, 2013) thinking and emoting (Swain, 2013) because, restating (Smagorinsky, 2013) "how we think and how we feel cannot be separated". Against this background, it may be maintained that cognition and emotion is inextricably attached (Michell, 2016; Pessoa, 2013; Poehner \& Swain, 2016; Smagorinsky, 2011; Smagorinsky, 2012; Smagorinsky, 2013; Swain \& Lapkin, 2013; Swain, 2013; Vadeboncoeur, 2013; Vadeboncoeur \& Collie, 2013). Similarly, there is a growing body of research in the neurosciences gradually indicating the interdependence of cognition and emotion. For example, Pessoa (2013) in his book on brain research The cognitive-emotional brain states: "emotion and cognition cannot be dissociated in the brain because 'affective' brain regions participate in cognition, on the one hand, and 'cognitive' brain regions participate in emotion”.

Although emotions seem to be crucial forces in intellectual development, this theme has been neglected in recent decades (Dewaele, Chen, Padilla, \& Lake, 2019; Gass, Behney, \& Plonsky, 2013; Prior, 2019; Swain, 2013). Viewed as "the elephants in the room - poorly studied, poorly understood, seen as inferior to rational thought" 
(Swain, 2013), it has not been given enough attention. Correspondingly, it may be suggested here that a similar situation seems to be applicable to sociocultural research in SLA (Zuengler \& Miller, 2006). In the discussion of cognitive and social theories, the authors evoke Sharwood Smith (1991) comparison of the cognitive to a "cake" and the social to "icing". Over the years an enormous amount of research has been dedicated to studies conducted from a purely cognitivist perspective (Atkinson, 2019; Prior, 2019) which usually views the mind, sometimes referred to as the soul, and the body as two independent lines. Inasmuch as its importance should not be questioned, it seems equally critical to acknowledge the emergence of the affective (Pavlenko, 2013) and social turn (Block, 2003) in SLA.

In his critical review essay, Atkinson (2019) turns the reader's attention to the fact that: "Our minds are in our bodies, and our bodies are in the world (...) And language - or, more accurately, embodied multimodal languageinvolving affective meaning-making - is a function of that nervous system in that body in that world, and therefore cannot be understood apart from it." In the same spirit, asking whether there might be dialectical processes among the individual, cognitive, affective and social variables contributing to L2 developmental processes, this paper probes (Vygotsky, 1987) assertion that: "Thought itself is engendered by motivation, i.e., by our desires and needs, our interests and emotions. Behind every thought there is an affective- volitional tendency, which holds the answer to the last 'why' in the analysis of thinking. A true and full understanding of another's thought is possible only when we understand its affective-volitional basis."

This provides the basis for the discussion of the possible interconnections within the spectrum of affect and/or cognition and/or social factors as illustrated in the examples of a few selected empirical and theoretical studies. It is, however, crucial to remind the reader that the studies might not even use this concept directly, but rather they capture aspects of it.

\section{POSSIBLE RESONANCE OF DIALECTICS IN OTHER STUDIES}

At the heart of Dar (2018) qualitative study are cognitive-affective components integrated into English curriculum texts in Pakistan and their impact on primary school children. The findings reveal that social emotional skills such as empathy and pro-social thinking taught through the selected texts can not only develop emphaticaffective skills, vital for children as future citizens, but can also generate better language development and academic engagement. This is a real contribution to the body of research on the possible cognitive affective co-relation in the educational context where educational activities interact with the "cognitive, affective and psychomotor domains" (Dar, 2018). From these lines of thought a possible dialectical unity among these variables can be inferred, even though it is not directly investigated.

In a similar manner, Butler (2017) looked at the correlation between affect (emotion and mood) and young learners' performance in task-based language teaching (TBLT) in English as a Foreign Language classes. She argues that SLA research should go beyond seeing the role of affect as independent from cognition and sheds light on the important, yet overlooked, fact that in the field of psychology a possible relationship between affect and cognition has been flourishing, while the opposite has been true for SLA research (Butler, 2017). What is more, intra-individual variability within individuals in relation to performance in TBLT tasks in the light of reciprocal connection between emotion and cognition has scarcely received any attention despite the fact that many teachers are concerned about their young learners' affective responses (p.729).

In this sense, by recognizing the scarcity of research in this area, Butler acknowledges the necessity of further research into the cognitive-affective integrated approach to teaching, which would seem beneficial for not only the further advancement of TBLT research but also the "wider context" (p.728). Calkins and Bell (2010) insist that research which incorporates cognition and emotion is vital to "any comprehensive conceptualization of development". This suggests that Butler's argument and analysis of previous studies might resonate with the notion of dialectical development and simultaneously call to mind Vygotsky's notion of perezhivanie when “an indivisible 
unity of personal characteristics and situational characteristics (...) are represented in the emotional experience [perezhivanie]' (Vygotsky, 1994).

In the same vein, in the exploration of the impact of the cognitive and non-cognitive components of cognitive conflict on cognitive change, (Hadjiachilleos, Valanides, \& Angeli, 2013) observed that the non-cognitive components not only had an impact on cognitive changes in 15 elementary and middle school students but also that their effect was highly individualistic. This implies that learning outcomes may vary across individuals due to their different affective responses to the cognitive conflict. The cognitive conflict suggests here the discrepancy between one's perception of cognitive abilities and external information (Lee \& Kwon, 2001). Although the material collected through semi-structured clinical interviews did not have as its aim second language development, but rather cognitive conflict in the context of the scientific phenomena of floating and sinking, it still serves as a significant example, and the need for a deeper investigation into not merely cognitive factors linked to cognitive conflict but also affective factors was also identified by the authors (Hadjiachilleos et al., 2013). These findings again appear to support the idea that there may be an Individual-Cognitive-Affective Facet to L2 development resembling the dialectical unity.

The same thought also seems to resonate in Heydarnejad, Ebrahimi, and Adel's (2019) more recent research. They carried out a quantitative empirical study to examine whether Emotion Based Language Instruction (EBLI) teaching, developed by Pishghadam, Adamson, and Shayesteh (2013) has any potential effect on EFL intermediate adult learners' speaking and listening skills. For this purpose, an IELTS pre- and post-test was used, and experimental and control groups were created to assess the Speaking and Listening skills of 57 first-year male and female students aged between 18 and 21, studying at one of the Higher Education institutions in Iran. Despite the potential limitations of this type of design, the results indicated a clear connection between emotions and oral skills, thereby confirming the findings of similar studies in the field. Specifically, the participants' oral (speaking and listening) skills significantly improved in the experimental group as opposed to the control group. This group showed some improvement, but it was not as important from a statistical perspective. The authors conclude that this might have further implications, for instance, for teaching designs and the syllabus in EFL/ESL contexts.

A similar theme emerges in Bown and White (2010) qualitative investigation into the regulation of affect among 12 female and 7 male learners of Russian aged from 18 to 45. Building on social cognitive theory and research on the intelligent processing of emotions, the data analysis of open-ended interviews and narrative journals revealed 476 references to emotions, revealing the leading role of emotions over other themes. Participants were found to experience different affective responses, both negative and positive, depending on the social and learning environments. Interestingly, negative ones seemed to dominate. The findings specifically evidenced the existence of the interdependence of emotion and cognition in such repetitive themes as emotion and decision-making, emotion and cognitive appraisal, and the intelligent processing of emotion. Moreover, social relationships, which were mainly evident in individualized intrusions, or their absence, also evoked emotional reactions in the participants. According to this study there may be a possible reciprocal relationship between affect and achievement; however, further research is required to "illuminate further the interdependence between the social context and cognitive processes in language learning” (p.348). From this it may again be claimed that contrastive elements may interweave and interact in a dialectical manner.

In a similar vein, following up on previous studies on complex dynamic systems theory (CDST) with a particular emphasis on the occurrence dynamic changes, Nematizadeh and Wood (2019) scrutinized the possible cognitive and affective connections between willingness to communicate (WTC) and second language (L2) fluency. The study involved two male and two female graduate students aged between 30 and 35-years old who had lived in Canada for nearly two years and whose native language was Farsi. An idiodynamic method enabled the researchers to observe any moment-to-moment shifts in WTC, whereas both a qualitative and quantitative approach allowed for looking in depth at the phenomena under scrutiny. The data analysis evidenced, for instance, three types of 
interactions between WTC and fluency: positive, negative and neutral, which, as the authors hold, appear to resemble a dynamic system. This sheds further light on the importance of the fact that the "WTC ebbs and flows (...) involved principally an interconnected interaction between affective states, linguistics sources, and cognitive processing capacity” (p.211).

These ebbs and flows appear to be corresponding with the work of Gaulin (2019). It is based on phenomenology as a research procedure, which views a particular phenomenon from subjective and individual perspectives. This qualitative study investigated the perceptions of an Intensive English Program (IEP) accredited by Higher Education institutions as experienced by fifteen Second Language (ESL) students. These experiences which ranged from linguistic, cognitive, affective to communal and spiritual were compared on a "continuum of experience paradigm" (p.161) and to "the facets of a crystal" (p.160), signifying not only their uniqueness and intricacy but also their subtle interconnectedness. It seems that there might be a "dialectical relationship between language and experience" (p.165).

On a similar note, Prior (2016) in his book Emotion and discourse in L2 narrative research on the basis of autobiographical interview data collected between 2004 and 2010 with adult immigrants, all refugees, living in Canada and the US, interprets "emotions as social actions" (p.1, italics in original). In this context, narrative and autobiographical research uncovers an array of variables at play where the subjective perceptions of self-clash with social realities in interactional, multi-layered and dynamic systems of exchanges loaded with emotions that are not always positive. Recognizing dissonance within the body of research on emotions itself, Prior (2019) echoes a similar idea in his paper by noting that emotions are not merely either intra-psychological or bio-psychological but also socio-contextual and consequently formed by such factors as cultures, languages or social relationships. There are also multi-semiotic, evaluative and moral elements attached to this which is a reminder of both the affective and dialectical dimensions of L2 developmental processes.

Along similar lines (Schumann, 1994) taking into account a neurobiological approach to brain mechanisms in the 1990s, states that inasmuch as cognitive and affective processes can be distinguished, neither of them can be separated. It is because in the brain cognition is "intimately integrated with the neural mechanisms for affect" (p.241). He concludes that dichotomizing both may produce dubious understandings of SLA (p. 239).

At this point it is worth recalling that in the early 1980s, Guiora (1983) observed in the Dialectic of Language Acquisition that according to which cognitive, affective and psychological factors meet in the interactive and reciprocal, yet conflicting, processes which contribute to foreign language learning, the role of a native language does not remain neutral. In the course of development both internal and external forces are fused to create "living language" (p.10). This type of language is not merely equated with a particular set of words and rules; on the contrary, it carries a psychological load and impacts on personality development. It is in this unique form of synthesis, that personality characteristics emerge (Guiora, 1982).

This dialectical dimension of the foreign language learning process was also captured in Tsvetkova (2019) quasi-experimental study of 50 high-school learners of English in Bulgaria. Seeing internal and external socialcultural characteristics, linguistic and non-linguistic features, inter- and intra-psychological processes as an inextricably connected, not polarized, dynamic system, the study confirmed the close relationship between L2 anxiety and L2 performance. This finding appears to stand as another reflection of dialectics. It thus can be repeated that an "affective-volitional tendency (...) holds the answer to the last 'why' in the analysis of thinking" (Vygotsky, 1987).

Lantolf and Swain (2020) in their chapter, Perezhivanie: The Cognitive-Emotional Dialectic within the Social Situation of Development, recognize the emergency and at the same time the importance of the dialectical interconnection between emotions and cognition in both L2 development as well as L2 teacher development. They acknowledge the existence of the dialectical unity not only between an individual and the social circumstances but 
also between emotions and cognition that form an individual in a particular external environment. Their appeal for cooperation among diverse theories and models of emotion to create alternatives should not go unnoticed (p.101).

\section{CONCLUDING REMARKS}

In the vein of open continuing debate in the field of SLA, the present paper has attempted to discuss and conceptualize the thought of dialectical unity in relation to L2 development. To this end, the variations of SLA theories have been recalled, the goal of which was not to focus on critical analysis. Instead, Vygotsky's (Vygossky, 1997b; Vygotsky, 1999) conception of dialectics has been expanded with the intention of opening up new questions and perspectives that are still in need of further investigation. In the context of dialectics, a wide range of conflicting forces such as linguistics, cognitive, affective and social interact, impact and intertwine in dialectical processes of L2 development. The ratios among them potentially might also affect personality/character as well as attitude to language learning and learning in general, depending on individual differences, learners' age and situational characteristics. Against this background a few exemplary studies were selected. These have all carried out research or provided theoretical debate on possible mutual relationships among different variables such as cognitive and/or affective and/or social aspects in L2 developmental processes regardless of the learners' ages.

Overall, the objective of this paper was to investigate how the dialectical thought process has been dealt with in the previous and current literature, without necessarily explicitly referring to it. The analysis suggests that such variables as cognition, affect and sociocultural factors may indeed co-exist to a greater or lesser extent in an ongoing dialectical development. Considering the fact that this approach is far from final, it is hoped that the insights presented here will form the basis for further inquiry into the concept of the dialectical harmony among conflicting variables in L2 development and this discussion can continue.

Funding: This study received no specific financial support.

Competing Interests: The author declares that there are no conflicts of interests regarding the publication of this paper.

\section{REFERENCES}

Appel, G., \& Lantolf, J. P. (1994). Speaking as mediation: A study of L1 and L2 text recall tasks. The Modern Language Journal, $78(4), 437-452$.

Atkinson, D. (2019). Beyond the brain: Intercorporeality and Co-operative action for SLA studies. The Modern Language Journal, 103(4), 724-738.Available at: https://doi.org/10.1111/modl.12595.

Baker, C., \& Jones, S. P. (1998). Encyclopedia of bilingualism and bilingual education. Clevedon: Multilingual Matters.

Baker, C. (2011). Foundations of bilingual education and bilingualism. Bristol: Multilingual Matters.

Barrs, M. (2017). Rediscovering vygotsky's concept of the ZPD: Stanley Mitchell's new translation of 'the problem of teaching. Changing English, 24(4), 345-358.

Bialystok, E., Craik, F. I., \& Luk, G. (2012). Bilingualism: Consequences for mind and brain. Trends in Cognitive Sciences, 16(4), $240-250$.

Block, D. (2003). The social turn in second language acquisition. Edinburgh, Scotland: Edinburgh University Press.

Bloomfield, L. (1933). Language. New York: Holt, Rinehart and Winston.

Bown, J., \& White, C. (2010). A social and cognitive approach to affect in SLA. International Review of Applied Linguistics in Language Teaching, 48(4), 331-353.Available at: https://doi.org/10.1515/iral.2010.014.

Butler, Y. G. (2017). The role of affect in intraindividual variability in task performance for young learners. Tesol Quarterly, 51(3), 728-737.Available at: https://doi.org/10.1002/tesq.385.

Calkins, S. D., \& Bell, M. A. (2010). Introduction: Putting the domains of development into perspective. In: S. D. Calkins \& M. A. Bell (Eds.), Child development at the intersection of emotion and cognition (pp. 3-13). Washington, DC: American Psychological Association. 
Chaiklin, S. (2003). The zone of proximal development in vygotsky's analysis of learning and instruction. In: A. Kozulin, B. Gindis, A.S. Ageyev, S.M. Miller (Eds.) Vygotsky's Educational Theory in Cultural Context (pp. 39-64). New York: Cambridge University Press.

Chomsky, N. (1959). Review of skinner's verbal behavior. Language, 35(1), 26-58.

Corder, S. P. (1974). Error analysis. In: J.L.P. Allen and S. P. Corder (Eds.). Techniques in applied linguistics. Oxford: Oxford University Press.

Cummins, J. (1976). The influence of bilingualism on cognitive strength: A synthesis of research findings and explanatory hypotheses. Working Papers on Bilingualism, No. 9 (pp. 1-43). Toronro, Canada: Ontario Institute for Studies in Education.

Cummins, J. (1996). Negotiating identities: Education for empowerment in diverse society. Ontario: California Association for Bilingual Education.

Cummins, J. (2000). Language, power and pedagogy: Bilingual children in the Crossfire. Clevedon: Multilingual Matters.

Dafermos, M. (2018). Rethinking cultural-historical theory: A dialectical perspective to vygotsky. Singapore: Springer.

Daniels, H. (2007). Pedagogy. In: H. Daniels, M. Cole, and J. Wertsch (Eds.), The Cambridge Companion to Vygotsky (pp. 307331). Cambridge: Cambridge University Press.

Daniels, H. (2008). Vygotsky and research. London: Routledge.

Daniels, H., Cole, M., \& Wertsch, J. (2007). Editors' introduction. In: H. Daniels, M. Cole, and J. Wertsch (Eds.), The Cambridge Companion to Vygotsky. Cambridge: Cambridge University Press.

Dar, F. (2018). Using texts to teach cognitive-affective curriculum. Journal of Education and Educational Development, 5(2), 28-44.

De Bot, K., Lowie, W., \& Verspoor, M. (2007). A dynamic systems theory approach to second language acquisition. Bilingualism, $10(1), 7-21$.

Dewaele, J., Chen, X., Padilla, A., \& Lake, J. (2019). The flowering of positive psychology in foreign language teaching and acquisition research. Frontiers in Psychology, 1O(2128), 1-13.Available at: https://doi.org/10.3389/fpsyg.2019.02128.

Douglas Fir Group. (2016). A transdisciplinary framework for SLA in a multilingual world. Modern Language Journal, 100(S1), 19-47.Available at: https://doi.org/10.1111/modl.12301.

Ellis, N. C. (2019). Essentials of a theory of language cognition. The Modern Language Journal, 103(Issue S1), 39-60.Available at: https://doi.org/10.1111/modl.12532.

Ellis, R. (2020). A short history of SLA: Where have we come from and where are we going? Language Teaching, 1-16.Available at: https://doi.org/10.1017/So26 1444820000038.

Gass, S. M., Behney, J., \& Plonsky, L. (2013). Second language acquisition: An introductory course (4th ed.). London: Routledge.

Gaulin, W. I. (2019). Phenomenology as a path to english as a second language (ESL) praxis, curriculum and theory-making. In: S. Sharma, A. Lazar (Eds) Rethinking 21 st Century Diversity in Teacher Preparation, K-12 Education, and School Policy. Theory, Research, and Practice (pp. 149-168). Cham, Switzerland: Springer.

Glassman, M. (2000). Negation through history: Dialectics and human development. New Ideas In Psychology, 18(1), 1-22.

Guiora, A. Z. (1982). Language, personality, and culture, or the Whorfian hypothesis revisited. In: M. Hines and W. Rutherford (Eds), ON TESOL'81 (pp. 169-177). Washington, D.C: Teachers of English to Speakers of Other Languages.

Guiora, A. Z. (1983). The dialectic of language acquisition. Language Learning, 33(5), 3-12.Available at: https://doi.org/10.1111/j.1467-1770.1984.tb01321.x.

Hadjiachilleos, S., Valanides, N., \& Angeli, C. (2013). The impact of cognitive and affective aspects of cognitive conflict on learners' conceptual change about floating and sinking. Research in Science \& Technological Education, 31(2), 133152.Available at: https://doi.org/10.1080/02635143.2013.811074.

Hall, J. K. (2020). A transdisciplinary framework for sla: essential understandings for L2 researchers and teachers. 3L: The Southeast Asian Journal of English Language Studies, 24(4), 1 - 12.

Heydarnejad, T., Ebrahimi, M. R., \& Adel, S. M. R. (2019). The influence of applying emotion based language instruction in teaching oral skills to EFL learners. International Journal of Instruction, 12(2), 275-288. 
Jablonski, S. (2002). Written speech development: A cultural-historical approach to the process of reading and writing ability acquisition. Psychology of Language and Communication, 6(2), 53-64.

Kozulin, A. (1990). Vygotsky's psychology: A biography of ideas: Harvard University Press.

Kozulin, A. (2003). Psychological tools and mediated learning. In: A. Kozulin, B. Gindis, A.S. Ageyev, S.M. Miller (Eds.) Vygotsky's Educational Theory in Cultural Context (pp. 23-49). New York: Cambridge University Press.

Krashen, S. (1984). Immersion: Why it words and what it has taught us. Language and Society, 12(1), 61-64.

Krashen, S. (1985). The input hypothesis: Issues and implications. New York: Longman.

Lantof, J. P., \& Thorne, S. L. (2006). Sociocultural theory and the genesis of second language development. Oxford: Oxford University Press.

Lantolf, J. P. (2003). Intrapersonal communication and internalization in the second language classroom. In: A. Kozulin, B. Gindis, A.S. Ageyev Miller (Eds.) Vygotsky's Educational Theory in Cultural Context (pp. 349-370). New York: Cambridge University Press.

Lantolf, J. P., \& Beckett, T. G. (2009). Sociocultural theory and second acquisition. Language Teaching, 42(4), 459-475.

Lantolf, J. P., \& Poehner, M. E. (2010). Dynamic assessment in the classroom: Vygotskian praxis for second language development. Language Teaching Research, 15(1), 11-33.

Lantolf, J. P., \& Swain, M. (2020). Perezhivanie: The Cognitive-emotional dialectic within the social situation of development. In: A. H. Al-Hoorie and P. D. MacIntyre (Eds.) Contemporary Language Motivation Theory: 60 Years Since Gardner and Lambert (pp. 80-108). Bristol, UK and Blue Ridge Submit, PA, USA: Multilingual Matters.

Lantolf, J., Thorne, S. L., \& Poehner, M. (2015). Sociocultural theory and second language development. In: B. van Patten and J. Williams (Eds.), Theories in Second Language Acquisition (pp. 207-226). New York: Routledge.

Larsen-Freeman, D., \& Cameron, L. (2008). Complex systems and applied linguistics. Oxford: Oxford University Press.

Larsen-Freeman, D. (2018). Looking ahead: Future directions in, and future research into, second language acquisition. Foreign Language Annals, 51(1), 55-72.Available at: https://doi.org/10.1111/flan.12314.

Lee, G., \& Kwon, J. (2001). What do we know about students' cognitive conflict in science classroom: A theoretical model of cognitive conflict process? Paper presented at the Proceedings of the 2001 AETS Annual Meeting, Costa Mesa, CA.

Lightbown, P. M., \& Spada, N. (2013). How languages are Learned. Oxford: Oxford University Press.

Liu, C. H., \& Matthews, R. S. (2012). Vygotsky's philosophy of learning. In: N.M. Seel (Eds.) Encyclopedia of the Sciences of Learning (3440-3443 ed.). Boston, MA: Springer.

Liu, D. (2015). A critical review of Krashen's input hypothesis: Three major arguments. Journal of Education and Human Development, 4(4), 139-146.

May, S. (2014). Disciplinary divides, knowledge construction, and the multilingual turn. In: S. May (Ed.). The multilingual turn. Implications for SLA, TESOL, and bilingual education (pp. 7-31). New York: Routledge.

Meier, G. (2017). The multilingual turn as a critical movement in education: assumptions, challenges and a need for reflection. Applied Linguistics Review, 8(1), 131-161.Available at: https://doi.org/10.1515/applirev-2016-2010.

Menezes, V. (2013). Second language acquisition: Reconciling theories. Open Journal of Applied Sciences, 3(7), 404-412.Available at: 10.4236/ojapps.2013.37050.

Mercer, N., \& Littleton, K. (2007). Dialogue and the development of children's thinking. London and New York: Routledge.

Michell, M. (2016). Finding the "prism”: Understanding Vygotsky's perezhivanie as an ontogenetic unit of child consciousness. International Research in Early Childhood Education, 7(1), 5-33.

Mitchell, R., \& Myles, F. (2004). Second language learning theories. London: Hodder Arnold.

Nematizadeh, S., \& Wood, D. (2019). Willingness to communicate and second language speech fluency: An investigation of affective and cognitive dynamics. Canadian Modern Language Review, 75(3), 197-215.Available at: https://doi.org/10.3138/cmlr.2017-0146.

Neupane, N. (2019). Second language acquisition as a discipline: A historical perspective. Journal of NELTA Gandaki, 2, 55-64.

Newman, F., \& Holzman, L. (1993). Lev Vygotsky: Revolutionary scientist. London and New York: Routledge. 
Ohta, A. S. (2016). Sociocultural theory and second/foreign language education. In: Van Deusen-Scholl N., May S. (Eds.), Second and Foreign Language Education. Encyclopedia of Language and Education (3rd ed.). Cham: Springer.

Ortega, L. (2014). Ways Forward for a Bi/Multilingual Turn in SLA. In: S. May (Ed.), The multilingual turn. Implications for SLA, TESOL, and bilingual education (pp. 32-53). New York: Routledge.

Pavlenko, A. (2013). The affective turn in SLA: From 'affective factors' to 'language desire' and 'commodification of affect. In: D. Gabrys-Barker and J. Bielska (Eds.), The affective dimension in second language acquisition (pp. 3-28). Bristol, UK: Multilingual Matters.

Pessoa, L. (2013). The cognitive-emotional brain. From interactions to integration. Cambridge, MA: MIT Press.

Pishghadam, R., Adamson, B., \& Shayesteh, S. (2013). Emotion-based language instruction (EBLI) as a new perspective in bilingual education. Multilingual Education, 3(9), 1-16.Available at: http://dx.doi.org/10.1186/2191-5059-3-9.

Poehner, M. E., \& Swain, M. (2016). L2 development as cognitive-emotive process. Language and Sociocultural Theory, 3(2), 219241.Available at: https://doi.org/10.1558/lst.v3i2.32922.

Prior, M. T. (2016). Emotion and discourse in L2 narrative research. Bristol: Multilingual Matters.

Prior, M. T. (2019). Elephants in the room: An "affective turn," or just feeling our way? The Modern Language Journal, 103(2), 516-527.Available at: https://doi.org/10.1111/modl.12573.

Robbins, D. (1999). Prologue. In: R. W. Rieber (Ed.), Collected Works of L.S. Vygotsky. Scientific Legacy (Vol. 6, pp. 5-12). New York: Kluwer Academic/Plenum Publishes.

Robbins, D. (2007). Redefining LS Vygotsky's non-classical psychology. Intercultural Pragmatics, 4(1), 85-97.Available at: https://doi.org/10.1515/ip.2007.005.

Schmidt, R. W. (1990). The role of consciousness in second language learning 1. Applied Linguistics, 11(2), 129-158.Available at: https://doi.org/10.1093/applin/11.2.129.

Schumann, J. H. (1994). Where is cognition?: Emotion and cognition in second language acquisition. Studies in Second Language Acquisition, 16(2), 231-242.Available at: https://doi.org/10.1017/s0272263100012894.

Selinker, L. (1972). Interlanguage. IRAL-International Review of Applied Linguistics in Language Teaching, 10(1-4), $209-232$.

Severac, P. (2017). Consciousness and affectivity: Spinoza and Vygotsky. Stasis, 5(2), 80-109.

Sharwood Smith, M. (1991). Plenary given at the second language research forum. Los Angeles: University of California.

Skinner, B. F. (1957). Verbal behavior. New York: Appleton-Century-Crofts.

Skutnabb-Kangas, T., \& Toukomaa, P. (1976). Teaching migrant children's mother tongue and learning the language of the host country in the context of sociocultural situation of the migrant family. Helsinki: The Finnish National Commission for UNESCO.

Smagorinsky, P. (2011). Vygotsky and literacy research: A methodological framework. Rotterdam: Sense Publishers.

Smagorinsky, P. (2012). Vygotsky. Journal of Language and Literacy Education, 8(1), 1-25.

Smagorinsky, P. (2013). What does Vygotsky provide for the 21 st-century language arts teacher? Language Arts, $90(3), 192-204$.

Swain, M. (1985). Communicative competence: Some roles of comprehensible input and comprehensible output in its development. In: S. Gass and C. Madden (Eds.), Input in Second Language Acquisition (pp. 235-253). Rowley, MA: Newbury House.

Swain, M. (2006). Languaging, agency and collaboration in advanced second language proficiency. In: H. Byrnes (Ed.) Advanced Language Learning: The Contribution of Halliday and Vygotsky (pp. 95-108). London: Continuum.

Swain, M., Kinnear, P., \& Steinman, L. (2011). Sociocultural theory in second language education: An introduction through narratives. Bristol: Multilingual Matters.

Swain, M., \& Lapkin, S. (2013). A Vygotskian sociocultural perspective on immersion education: The L1/L2 debate. Journal of Immersion and Content-Based Education, 1(1), 101-129.Available at: https://doi.org/10.1075/jicb.1.1.05swa.

Swain, M. (2013). The inseparability of cognition and emotion in second language learning. Language Teaching, 46(2), 195207.Available at: https://doi.org/10.1017/s0261444811000486. 
Tan, K. H., \& Shojamanesh, V. (2019). Usage-based and universal grammar-based approaches to second language acquisition [Online First], IntechOpen. Retrieved from: https://www.intechopen.com/online-first/usage-based-and-universalgrammar-based-approaches-to-second-language-acquisition.

Tappan, M. B. (1997). Language, culture, and moral development: A Vygotskian perspective. Developmental Reviere, 17(1), 78100.Available at: https://doi.org/10.1006/drev.1996.0422.

Tappan, M. B. (1998). Sociocultural psychology and caring pedagogy: Exploring Vygotsky's" Hidden Curriculum". Educational Psychologist, 33(1), 23-33.Available at: https://doi.org/10.1207/s15326985ep3301_2.

Thorndike, E. (1932). The fundamentals of learning. New York: Columbia Teachers College.

Tsvetkova, M. (2019). Non-linguistic factors in classroom foreign language performance, pedagogy. Bulgarian Journal of Educational Research and Practice, 91(6), 848-870.

Vadeboncoeur, J. A. (2013). Framing achievement when learning is unified. The concept of unity in Vygotsky's theory and methodology. In: S. Phillipson and K.Y.L. Ku and S. N. Phillipson (Eds.), Constructing Educational Achievement: A sociocultural perspective (pp. 13-25). Oxon and New York: Routledge.

Vadeboncoeur, J. A., \& Collie, R. J. (2013). Locating social and emotional learning in schooled environments: A Vygotskian perspective on learning as unified. Mind, Culture, and Activity, 20(3), 201-225.Available at: https://doi.org/10.1080/10749039.2012.755205.

Van Compernolle, R. V. (2015). Interaction and second language development: A vygotskian perspective. Amsterdam: John Benjamins Publishing Company.

Van Der Veer, R. (2007). Lev Vygotsky. London: Continuum International Publishing Group.

Van Der Veer, R., \& Yasnitsky, A. (2011). Vygotsky in English: What still needs to be done. Integrative Psychological and Behavioral Science, 45, 475-493.Available at: 10.1007/s12124-011-9172-9.

Vasileva, O., \& Balyasnikova, N. (2019). (Re) Introducing Vygotsky's thought: From historical overview to contemporary psychology. Frontiers in Psychology, 10 (1515), 1- 15.Available at: https://doi.org/10.3389/fpsyg.2019.01515.

Veresov, N. (2004). Zone of proximal development (ZPD): The hidden dimension? In: A. Ostern and R. Heila-Ylikallio (Eds.), Sprak som kultur - brytningar I tidoch rum. - Language as culture - tensions in time and space (Vol. 1, pp. 13-30). Vasa: Pedagogiska Fakulteten.

Veresov, N. (2016). Perezhivanie as a phenomenon and a concept: Questions on clarification and methodological meditations. Cultural-Historical Psychology, 12(3), 129-148.Available at: https://doi.org/10.17759/chp.2016120308.

Veresov, N., \& Fleer, M. (2016). Perezhivanie as a theoretical concept for researching young children's development. Mind, Culture, and Activity, 23(4), 325-335.Available at: https://doi.org/10.1080/10749039.2016.1186198.

Vygotsky, L. S. (1987). The collected works of L. S. Vygotsky. Problems of General Psychology. Including the Volume Thinking And Speaking. (R.W. Rieber and A.S. Carton, Eds.) (Vol. 1). New York: Plenum Press.

Vygotsky, L. S. (1994). The problem of the environment. In: R. van der Veer and J. Valsiner (Eds) The Vygotsky Reader (pp. 338-354). Oxford: Blackwell.

Vygotsky, L. S. (1997b). The collected works of L. S. Vygotsky. The History of the Development of Higher Mental Functions. (R.W. Rieber, ed.) (Vol. 4). New York and London: Plenum Press.

Vygotsky, L. S. (1998). The collected works of L. S. Vygotsky. Child Psychology. (R.W. Rieber, ed.) (Vol. 5). New York: Springer Science \& Business Media, LLC.

Vygotsky (1999). The collected works of L.S. Vygotsky. Scientific Legacy, (R.W. Rieber, ed.) (Vol. 6). New York: Kluwer Academic/Plenum Publishes.

Vygotsky, L. S. (1997a). The collected works of L. S. Vygotsky. Problems of the Theory and History of Psychology (R.W. Rieber and J. Wolloc, Eds.) (Vol. 4). New York and London: Plenum Press.

Watts-Taffe, S., \& Truscott, D. M. (2000). Focus on research: Using what we know about language and literacy development for ESL students in the mainstream classroom. Language Arts, 77(3), 258-265.Available at: https://doi.org/10.2307/818629. 
Wertsch, J. V. (1985). Vygotsky and the social formation of mind. Cambridge, MA: Harvard University Press.

Wertsch, J. V. (2007). Mediation. In: H. Daniels, M. Cole, and J.V. Wertsch (Eds.), The Cambridge Companion to Vygotsky (pp. 178-192). Cambridge: Cambridge University Press.

Wong, W.-C. (2006). Understanding dialectical thinking from a cultural-historical perspective. Philosophical Psychology, 19(2), 239-260.Available at: https://doi.org/10.1080/09515080500462420.

Yaroshevsky, M. G. (1999). Epilogue. In: R. W. Rieber (Ed.), The collected works of L. S. Vygotsky. Scientific legacy (Vol. 6, pp. 245-266). New York: Kluwer Academic/Plenum Publishes.

Zuengler, J., \& Miller, E. R. (2006). Cognitive and sociocultural perspectives: Two parallel SLA worlds? TESOL Quarterly, 4O(1), 35-58.Available at: https://doi.org/10.2307/40264510.

Views and opinions expressed in this article are the views and opinions of the author(s), International Journal of English Language and Literature Studies shall not be responsible or answerable for any loss, damage or liability etc. caused in relation to/arising out of the use of the content. 